\title{
LOSS OF PROTECTIVE ANTIGEN, HISTAMINE-SENSI- TISING FACTOR AND ENVELOPE POLYPEPTIDES IN CULTURAL VARIANTS OF BORDETELLA PERTUSSIS
}

\author{
A. C. Wardlaw, R. Parton and Margaret J. Hooker \\ Department of Microbiology, Glasgow University, Alexander Stone Building, \\ Garscube Estate, Bearsden, Glasgow
}

\begin{abstract}
Plate V
ReCently, Parton and Wardlaw (1974 and 1975) reported that cell-envelopes of eight strains of phase-I Bordetella pertussis gave complex but almost identical patterns of polypeptide bands when analysed by SDS-PAGE (sodium-dodecylsulphate-polyacrylamide-gel electrophoresis). Envelopes from five phase-IV variants gave patterns similar to those of phase I except that two major bands were diminished or absent. These same bands were also attenuated in envelopes from two phase-I strains that had been grown in a high-magnesium medium to yield C-mode cells. The possible biological function of the two variable bands has not been established. There are, however, reports that phase-IV and $\mathrm{C}$-mode cultures of $B$. pertussis are deficient in protective antigen (PA), histaminesensitising factor (HSF) and agglutinogens (Kind, 1953; Kasuga et al., 1954; Eldering, Eveland and Kendrick, 1962; Holt and Spasojevic, 1968; Aprile, 1972; Parton and Wardlaw, 1975). We therefore speculated that the two variable bands might be associated with one or more of the above biological activities of phase-I cells.
\end{abstract}

B. pertussis shows two distinct types of variation, namely " phase variation" (Leslie and Gardner, 1931) which appears to be genotypic, and " antigenic modulation " (Lacey, 1951, 1960 ) which is phenotypic and produced by growth on certain media. In antigenic modulation three modes, $\mathrm{X}$, I and $\mathrm{C}$ have been described. X-mode got its name from the yellowishochre (xanthic) hue of the confluent growth of freshly isolated (phase-I) organisms on BordetGengou (BG) medium. C (cyanic) describes the greyish-blue appearance of the growth on BG medium containing a high level of $\mathrm{MgSO}_{4}$ or other salts. Between these two extreme forms, an intermediate (I) mode was found. The modes were principally distinguished by agglutination tests, $\mathrm{C}$-mode organisms being only poorly agglutinable by $\mathrm{X}$-mode antisera and vice versa. In addition, $\mathrm{C}$-mode cells were less toxic for mice and less virulent by the intranasal route. They also autolysed more readily but were much less easily flocculated by gold and mercuric chlorides. Another striking difference was in antigenicity, since hightitre X-mode, but not $\mathrm{C}$-mode agglutinating sera could be raised in rabbits, mice, rats or guinea pigs. Only fowls and turkeys gave satisfactory responses to $\mathrm{C}$-mode cells. These

Received 20 June 1975; accepted 16 Sept. 1975.

J. MED. MICROBIOL.-VOL. 9 (1976)

89 
TABLE I

Variants of $X$ medium

\begin{tabular}{|c|c|c|}
\hline $\begin{array}{l}\text { Designation } \\
\text { of medium }\end{array}$ & $\begin{array}{l}\text { Component of } X \text { medium } \\
\text { altered (per litre) }\end{array}$ & $\begin{array}{l}\text { Additional component } \\
\text { (per litre) }\end{array}$ \\
\hline $\begin{array}{l}\text { XC } \\
\text { C } \\
\text { CC } \\
\text { NA500 } \\
\text { NA1 } \\
\text { Nd500 }\end{array}$ & $\begin{array}{l}\mathrm{NaCl} \text { reduced to } 4 \mathrm{~g} \\
\mathrm{NaCl} \text { omitted } \\
\mathrm{NaCl} \text { omitted } \\
\text { Nicotinamide omitted } \\
\text { Nicotinamide omitted } \\
\text { Nicotinamide increased }\end{array}$ & $\begin{array}{l}\mathrm{MgSO}_{4} .7 \mathrm{H}_{2} \mathrm{O} 1 \mathrm{~g} \\
\mathrm{MgSO}_{4} .7 \mathrm{H}_{2} \mathrm{O} 5 \mathrm{~g} \\
\mathrm{MgSO}_{4} .7 \mathrm{H}_{2} \mathrm{O} 10 \mathrm{~g} \\
\text { Nicotinic acid } 500 \mathrm{mg} \\
\text { Nicotinic acid } 1 \mathrm{mg} \\
\text { Nicotinamide } 500 \mathrm{mg} \\
\text { final concentration }\end{array}$ \\
\hline $\begin{array}{l}\mathrm{Na}_{2} \mathrm{SO}_{4} \\
\text { Succinate }\end{array}$ & $\begin{array}{l}\mathrm{NaCl} \text { omitted } \\
\mathrm{NaCl} \text { omitted }\end{array}$ & $\begin{array}{l}\mathrm{Na}_{2} \mathrm{SO}_{4} 6 \cdot 12 \mathrm{~g} \\
\left(\mathrm{CH}_{2}, \mathrm{COONa}\right)_{2} .6 \mathrm{H}_{2} \mathrm{O} 11 \cdot 6 \mathrm{~g}\end{array}$ \\
\hline
\end{tabular}

observations suggest that the surfaces of $\mathrm{X}$ - and $\mathrm{C}$-mode organisms are fundamentally different.

The object of this investigation was to determine by direct experiment whether PA and HSF and the two variable bands were closely correlated. For this purpose, cultures were grown in media known to suppress PA and HSF and these were compared with normal phase-I cultures.

\section{MATERIALS AND METHODS}

Strains. Five phase-I B. pertussis strains from the previous study (Parton and Wardlaw, 1975) were used: no. 18334, a vaccine strain from the Connaught Laboratories, Toronto; no. 134, Pillemer's strain; no. NCTC10739 (Kendrick's 18-323) a challenge strain for the mouse protection test; and nos. GL353Z and L-84 from Dr Jean Dolby.

Media. BG Medium (Oxoid Ltd) was prepared according to the manufacturer's recommendations. The medium was dispensed in $15-\mathrm{ml}$ amounts in $50 \times 13 \mathrm{~mm}$ plastic petri dishes.

$\mathrm{X}$ medium, which was used in our previous paper as "Hornibrook medium ", was slightly modified from the original formula of Hornibrook (1939). Each litre contained $\mathrm{NaCl} 5 \mathrm{~g}, \mathrm{KCl} 0.2 \mathrm{~g}, \mathrm{~K}_{2} \mathrm{HPO}_{4} 0.25 \mathrm{~g}, \mathrm{MgCl}_{2} .6 \mathrm{H}_{2} \mathrm{O} 25 \mathrm{mg}, \mathrm{CaCl}_{2} 2 \mathrm{mg}$, Casamino Acids (Difco, technical) $10 \mathrm{~g}$, soluble starch (BDH) $1 \mathrm{~g}$, nicotinamide $1 \mathrm{mg}$ and glutathione $10 \mathrm{mg}$. The medium (without glutathione) was adjusted to $\mathrm{pH} 7.0$ with $c .45 \mathrm{mg}$ of $\mathrm{Na}_{2} \mathrm{CO}_{3}$, dispensed in 100-ml amounts in Roux bottles and sterilised by autoclaving at $121^{\circ} \mathrm{C}$ for $15 \mathrm{~min}$. The glutathione, as a $0 \cdot 1 \%(\mathrm{w} / \mathrm{v})$ solution, was sterilised by Seitz filtration and added separately. The designations and descriptions of a number of variants of $X$ medium are given in table $\mathrm{I}$.

When suspending pertussis organisms for culture inoculation or mouse challenge, a casamino-acid solution of the following composition per litre was used: Casamino Acids, $10 \mathrm{~g}, \mathrm{NaCl} 5 \mathrm{~g}, \mathrm{MgCl}_{2} .6 \mathrm{H}_{2} \mathrm{O} 0 \cdot 1 \mathrm{~g}$ and $\mathrm{CaCl}_{2} 16 \mathrm{mg}$. The $p \mathrm{H}$ was adjusted to $7 \cdot 1$ with $c$. $2.5 \mathrm{ml}$ of $\mathrm{M}-\mathrm{NaOH}$ and the medium sterilised by autoclaving at $121^{\circ} \mathrm{C}$ for $15 \mathrm{~min}$.

Growth of cultures. Stock cultures were grown on BG medium at $35^{\circ} \mathrm{C}$ for $2-3$ days in petri dishes placed in a closed plastic box containing a beaker of water to saturate the atmosphere. For growth on a larger scale, lawn cultures from three dishes were suspended in $10 \mathrm{ml}$ of casamino-acid solution and $1 \mathrm{ml}$ was added to each Roux bottle of liquid medium. The bottles were incubated flat at $35^{\circ} \mathrm{C}$ for 3 days, with daily shaking by hand. After checking the purity of each Roux bottle by gram stain, cells were harvested by centifugation at $6000 \mathrm{~g}$ for $30 \mathrm{~min}$, at $5^{\circ} \mathrm{C}$.

A portion of each cell harvest was made into vaccine by suspension in $0.85 \%(w / v)$ 
$\mathrm{NaCl}$ solution and heating for $20 \mathrm{~min}$. at $56^{\circ} \mathrm{C}$. Thiomersal $(0 \cdot 1 \mathrm{mg}$ per $\mathrm{ml}$, final concentration) was added as a preservative to the cooled suspension. The concentration of bacteria in the vaccine was determined (before heating) by the dilution factor needed to give an opacity equal to that of the World Health Organisation International Standard of 10 opacity units per $\mathrm{ml}$. This factor multiplied by 10 gave the opacity unitage of the undiluted suspension.

Envelope preparation. Cells were disrupted in an X-Press (LKB Instruments Ltd, South Croydon, Surrey) and envelopes prepared as described previously (Parton and Wardlaw, 1975).

Electrophoresis of envelope proteins. Slab-gel electrophoresis was done with the discontinuous sodium dodecyl sulphate (SDS) buffer system of Laemmli (1970) as used by Ames (1974). Separating and stacking gels contained 10 and $5 \%(\mathrm{w} / \mathrm{v})$ of acrylamide respectively. Both the gels and the electrode buffer contained SDS $0.1 \%(\mathrm{w} / \mathrm{v})$. The dimensions of the slabs were $8.0 \times 7.0 \times 0.3 \mathrm{~cm}$, the separating gels being $6.0 \times 7.0 \times 0.3 \mathrm{~cm}$.

Envelope samples were adjusted to contain $2 \mathrm{mg}$ of protein per $\mathrm{ml}$ as determined by the method of Herbert, Phipps and Strange (1971). To dissolve the envelopes, a 0.5-ml sample was added to $0.5 \mathrm{ml}$ of $0.125-\mathrm{M}$ Tris- $\mathrm{HCl}$ buffer at $p \mathrm{H} 6.8$ containing SDS $4 \%(\mathrm{w} / \mathrm{v}), \beta$ mercaptoethanol $10 \%(\mathrm{v} / \mathrm{v})$, glycerol $20 \%(\mathrm{v} / \mathrm{v})$ and bromophenol blue $0.002 \%(\mathrm{w} / \mathrm{v})$ and the mixture was heated at $100^{\circ} \mathrm{C}$ for $5 \mathrm{~min}$. The volume of each sample applied to the gels was 25 or $50 \mu 1$.

Electrophoresis was done in a Uniscil slab-gel electrophoresis unit (Universal Scientific Ltd, London) at a constant current of $15 \mathrm{~mA}$ per gel for $c .2 \mathrm{~h}$. Staining and destaining was by the method of Weber and Osborn (1969).

For molecular-weight determinations, the following marker proteins were run under identical conditions: bovine serum albumin (molecular weight, $67 \mathrm{k}$, i.e., 67000 daltons, Sigma Chemical Co., St Louis, Mo, USA); egg albumin (45k, Sigma); bovine pancreatic chymotrypsinogen (25.7k, Miles-Seravac, Maidenhead); trypsin (23k, Armour Pharmaceutical Co. Ltd, Eastbourne); and horse-heart cytochrome C (11.7k, Koch-Light). Protein bands are referred to by the estimated molecular weight obtained by interpolation on the scale provided by the marker proteins.

Densitometer traces of stained gels were obtained by means of a Joyce Loebl ultraviolet scanner with an effective scanning aperture of $0.05 \mathrm{~mm}$ and fitted with a $280-\mathrm{nm}$ interference filter.

Assay of $P A$ and HSF. Protective antigen was assayed by an intracerebral mouseprotection test essentially as described in the British Pharmacopoeia (1973). The mice were of a closed colony bred from the Charles River CD-1 strain. They were 3-4 weeks old at the time of immunisation. The challenge strain was B. pertussis no. NCTC10739 that had had its virulence enhanced by several passages through mouse brain.

HSF was assayed as described by Wardlaw and Jakus (1966), except that the mice were of the above strain and were 7-9 weeks old at the time of injection of vaccine.

Results of both the PA and the HSF tests were analysed by the probit method by means of a computer programme. All the reported results came from at least two independent tests, and the relative potencies and $95 \%$ confidence limits were calculated from the weighted values of the individual assays. Each assay was designed to provide a comparison of the PA or HSF activity of a culture from a variant medium with that of the culture of the same strain from $\mathrm{X}$ medium. Relative potencies were calculated with the $\mathrm{X}$-medium vaccine as standard.

\section{RESULTS}

\section{Cultures from $X$ and $C$ media}

B. pertussis strains $18334,134, \mathrm{~L}-84,10739$ and GL353Z were grown in X and $\mathrm{C}$ media to give normal (phase-I, $\mathrm{X}$-mode) and variant ( $\mathrm{C}$-mode) cultures 
TABLE II

Protective-antigen $(P A)$ and histamine-sensitising-factor (HSF) activities of vaccines from five Bordetella pertussis strains grown in $X$ and $C$ media

\begin{tabular}{|c|c|c|}
\hline \multirow{2}{*}{$\underset{\text { number }}{\text { Strain }}$} & \multicolumn{2}{|c|}{$\begin{array}{l}\text { Potency of C-vaccine relative to X-vaccine } \\
\text { (and } 95 \% \text { confidence limits) in respect of }\end{array}$} \\
\hline & $\mathbf{P A}$ & HSF \\
\hline $\begin{array}{l}18334 \\
134 \\
\text { L-84 } \\
10739 \\
\text { GL } 3532\end{array}$ & $\begin{array}{c}0.041(0.021,0.078) \\
0.026^{*} \\
0.082(0.024,0.32) \\
0.16(0.02,0.78) \\
<0.016^{*}\end{array}$ & $\begin{array}{l}0.03(0.02,0.046) \\
0.09(0.04,0.21) \\
0.043(0.030,0.062) \\
0.18(0.08,0 \cdot 37) \\
0.18(0.01,4)\end{array}$ \\
\hline
\end{tabular}

* Limits not calculable from computer print-out because of very low potency.

respectively. Each cell harvest was divided into two portions one of which was made into vaccine and the other into cell-envelopes.

Table II shows the results of the intracerebral mouse-protection tests made to compare PA activities of the $\mathrm{X}$ - and $\mathrm{C}$-mode vaccines from each strain. Strain 18334 was studied more fully than the others. Three batches of X-and $\mathrm{C}$-mode vaccines were prepared from this strain and two valid assays obtained on each. In all, the $\mathrm{C}$-mode vaccines had a weighted mean relative potency of 0.041 , or about $4 \%$ of their X-mode counterparts. The other four $B$. pertussis strains gave qualitatively similar results, with the $\mathrm{C}$-mode vaccines having between $2 \%$ and $16 \%$ of the potency of the corresponding X-mode preparations.

In general, C-mode vaccines had such low potency that considerable difficulty was experienced in obtaining valid assays of satisfactory precision. Several assays had to be rejected because of significant deviations from linearity or parallelism of the dose-response curves, and confidence limits tended to be rather wide because of the poor responses to the C-mode preparations. Even the wide confidence limits shown in table II were obtained only after tests with over 1200 mice.

The results of HSF tests on the same vaccines are also reported in table II. As before, strain 18334 was studied most extensively. It yielded C-mode vaccines that showed a weighted mean relative potency of 0.03 , or $3 \%$ of the $\mathrm{X}$-mode reference preparations. The other strains showed a similar substantial reduction in HSF potency of C-mode vaccines and, with four of the five strains, relatively narrow confidence limits were obtained. Inspection of these limits suggest that the different strains varied significantly in the extent of reduction in HSF produced by growth in C medium. For example, strain 18334 in the C-mode had only $3 \%$ of the HSF of the same strain in the X-mode, whereas strain 10739 in the C-mode had $18 \%$ of the HSF of its X-mode counterpart.

Cell-envelopes from each $\mathrm{X}$ - and $\mathrm{C}$-mode culture were analysed by SDSPAGE in slab gels. As reported previously but with a different electrophoretic 


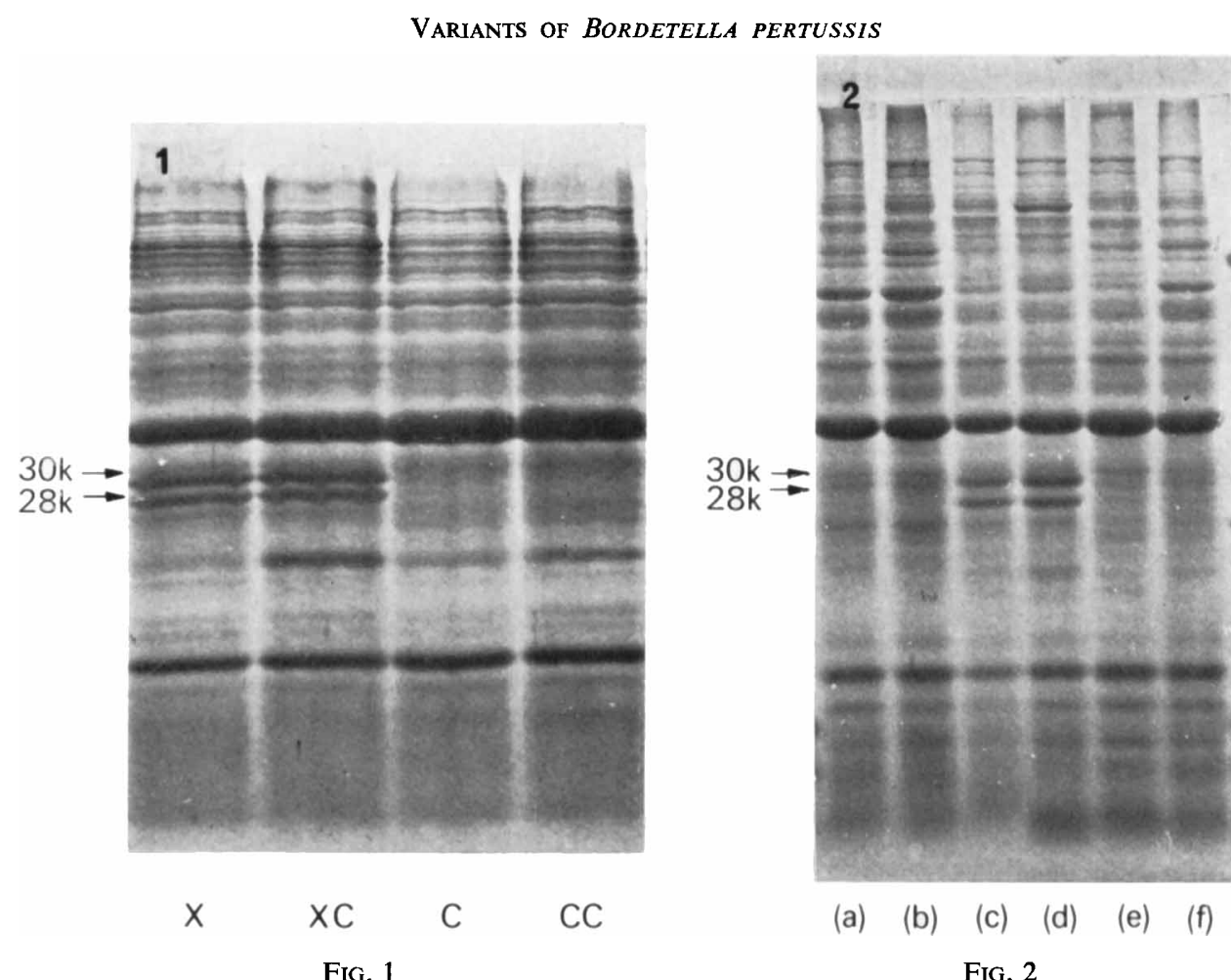

FIG. 1.-Envelope protein profiles of Bordetella pertussis strain 18334 grown in normal medium (X) or in media containing various concentrations of $\mathrm{MgSO}_{4}$ (see table I).

FIG. 2.-Envelope protein profiles of $B$. pertussis strain GL353Z; (a) phase I grown in NA500 medium; $(b)$ phase IV grown in X medium; $(c)$ phase I grown in X medium; and strain 134 grown in $(d)$ X medium; $(e)$ C medium; $(f)$ NA500 medium. 
TABLE III

$P A$ and HSF activities, and sodium-dodecyl-sulphate-polyacrylamide-gel electrophoresis (SDS-PAGE) lines, in cultures of B. pertussis strain 18334 from media with different concentrations of $\mathrm{Mg}^{2+}$

\begin{tabular}{|c|c|c|c|c|c|}
\hline \multirow{2}{*}{$\begin{array}{l}\text { Culture } \\
\text { medium }\end{array}$} & \multirow{2}{*}{$\underset{\text { concentration }}{\mathbf{M g}^{2+}}$} & \multicolumn{2}{|c|}{$\begin{array}{l}\text { Potency of vaccine relative to } X \text {-vaccine } \\
\text { (and } 95 \% \text { confidence limits) in respect of }\end{array}$} & \multicolumn{2}{|c|}{$\begin{array}{l}\text { SDS-PAGE lines } \\
\text { in cell-envelopes }\end{array}$} \\
\hline & & PA & HSF & $28 \mathrm{k}$ & $30 \mathrm{k}$ \\
\hline $\begin{array}{l}\mathrm{X} \\
\mathrm{XC} \\
\mathrm{C} \\
\mathrm{CC}\end{array}$ & $\begin{array}{l}0 \cdot 12 \\
4 \\
20 \\
41\end{array}$ & $\begin{array}{l}1 \cdot 0 \\
0.73(0 \cdot 13,3 \cdot 8) \\
0.041(0.021,0.078) \\
0.054(0.02,0 \cdot 15)\end{array}$ & $\begin{array}{c}1 \cdot 0 \\
1.9(1 \cdot 1,3 \cdot 1) \\
0 \cdot 03(0.02,0.046) \\
0.056(0.031,0 \cdot 10)\end{array}$ & $\begin{array}{l} \pm \\
\pm \\
-\end{array}$ & $\begin{array}{l}+ \\
\pm \\
\pm\end{array}$ \\
\hline
\end{tabular}

system (Parton and Wardlaw, 1975), the C-mode cultures gave band patterns very similar to those of $\mathrm{X}$-mode cultures but obviously lacking two major bands (figs. 1 and 2). In the previous gel system these bands, designated $B$ and $\mathrm{C}$, were found to have molecular weights of $33 \cdot 5 \mathrm{k}$ and $30 \mathrm{k}$ respectively. However, in the present gel system the molecular weights were estimated to be $30 \mathrm{k}$ and $28 \mathrm{k}$ respectively.

$\mathrm{X}$-mode envelopes of all five $B$. pertussis strains showed these prominent $30 \mathrm{k}$ and $28 \mathrm{k}$ bands but they were not apparent in any of the C-mode preparations. Densitometer tracings of the band patterns of strain $18334 \mathrm{X}$ - and $\mathrm{C}$-mode envelopes are given in fig. 3 and provide an alternative method of visualisation.

\section{Effect of different concentrations of $\mathrm{MgSO}_{4}$}

Since $\mathrm{MgSO}_{4} \cdot 7 \mathrm{H}_{2} \mathrm{O}$ at the concentration of $5 \mathrm{~g}$ per litre $(20 \mathrm{~mm})$ in $\mathrm{C}$ medium gave cultures with diminished PA, HSF and 28k and 30k gel lines, the effect of lower and higher concentrations of this salt was examined. Parallel cultures of strain 18334 were therefore grown in media with the following concentrations of $\mathrm{Mg}^{2+}: 0.12 \mathrm{~mm}$ (X medium), $4 \mathrm{~mm}$ (XC medium), $20 \mathrm{~mm}$ (C medium) and $41 \mathrm{~mm}$ (CC medium). As before, each culture harvest was apportioned for making vaccine and cell-envelopes, and PA and HSF tests and SDS-PAGE were done. The results (table III and fig. 1) show that cultures grown in 0.12 and $4 \mathrm{~mm} \mathrm{Mg}^{2+}$ (X and XC media) had similar levels of PA and HSF and prominent $28 \mathrm{k}$ and $30 \mathrm{k}$ gel lines, while cultures in 20 and $41 \mathrm{mM} \mathrm{Mg}^{2+}$ ( $\mathrm{C}$ and $\mathrm{CC}$ media) were markedly deficient in all these components. The change in properties of the cultures from the X-mode type to the C-mode type thus occurred when the $\mathrm{Mg}^{2+}$ level in the medium was raised from 4 to $20 \mathrm{~mm}$.

\section{Effect of high and low levels of nicotinic acid and nicotinamide}

$\mathrm{X}$ medium contains nicotinamide $1 \mathrm{mg}$ per litre, but equally good growth may be obtained with nicotinic acid $1 \mathrm{mg}$ per litre. Pusztai and Joó (1967) 
TABLE IV

$P A$ and HSF activities, and SDS-PAGE lines, in cultures of $B$. pertussis strain 18334 from media with different concentrations of nicotinic acid and nicotinamide

\begin{tabular}{|c|c|c|c|c|}
\hline \multirow{2}{*}{$\begin{array}{l}\text { Culture } \\
\text { medium }\end{array}$} & \multicolumn{2}{|c|}{$\begin{array}{l}\text { Potency of vaccine relative to } X \text {-vaccine } \\
\text { (and } 95 \% \text { confidence limits) in respect of }\end{array}$} & \multicolumn{2}{|c|}{$\begin{array}{l}\text { SDS-PAGE lines } \\
\text { in cell-envelopes }\end{array}$} \\
\hline & PA & HSF & $28 \mathrm{k}$ & $30 \mathrm{k}$ \\
\hline $\begin{array}{l}\text { X } \\
\text { Nd500* } \\
\text { NA1* } \\
\text { NA500* }\end{array}$ & $\begin{array}{c}1 \cdot 0 \\
1 \cdot 1(0.07,21) \\
0 \cdot 51(0 \cdot 12,2 \cdot 1) \\
0.05(0.003,1 \cdot 09)\end{array}$ & $\begin{array}{c}1 \cdot 0 \\
1 \cdot 2(0.61,2 \cdot 2) \\
0 \cdot 38(0.25,0 \cdot 57) \\
0 \cdot 19(0.08,0 \cdot 41)\end{array}$ & $\begin{array}{l}+ \\
+ \\
+ \\
-\end{array}$ & $\begin{array}{l}+ \\
+ \\
+\end{array}$ \\
\hline
\end{tabular}

TABLE V

$P A$ and HSF activities, and SDS-PAGE lines, in cultures of B. pertussis strains 134 and $G L 353 Z$ from $X$ and $N A 500$ media

\begin{tabular}{|c|c|c|c|c|c|}
\hline \multirow{2}{*}{$\begin{array}{c}\text { Strain } \\
\text { number }\end{array}$} & \multirow{2}{*}{$\begin{array}{l}\text { Culture } \\
\text { medium }\end{array}$} & \multicolumn{2}{|c|}{$\begin{array}{l}\text { Potency of vaccine relative to X-vaccine } \\
\text { (and } 95 \% \text { confidence limits) in respect of }\end{array}$} & \multicolumn{2}{|c|}{$\begin{array}{l}\text { SDS-PAGE lines } \\
\text { in cell-envelopes }\end{array}$} \\
\hline & & PA & HSF & $28 \mathrm{k}$ & $30 \mathrm{k}$ \\
\hline GL $353 Z$ & $\begin{array}{c}X \\
\text { NA500 } \\
X \\
\text { NA500 }\end{array}$ & $\begin{array}{l}1.0 \\
0.006^{*} \\
1.0 \\
0.001\end{array}$ & $\begin{array}{c}1 \cdot 0 \\
0.035(0.008,0 \cdot 16) \\
1 \cdot 0 \\
0 \cdot 18(0.007,4 \cdot 4)\end{array}$ & $\begin{array}{l} \pm \\
\pm \\
+\end{array}$ & $\frac{+}{+}$ \\
\hline
\end{tabular}

$+=$ Present $;-=$ absent

* Limits not calculable from computer print-out because of very low potency.

showed that when the nicotinic-acid concentration in $B$. pertussis liquid culture-medium was raised from $1 \mathrm{mg}$ per litre to $500 \mathrm{mg}$ per litre, the PA and HSF activities of the corresponding vaccines fell substantially. With three different strains, the vaccines from high-nicotinic-acid medium had 5.5, 14 and $20 \%$ of the PA that was present in the low-nicotinic-acid reference preparations. The corresponding HSF activities were 36,56 and $53 \%$ of the controls respectively.

In the present investigation, nicotinic acid $500 \mathrm{mg}$ per litre was added to $\mathrm{X}$ medium and the cultures analysed as before. In addition, for symmetry of experimental design, the effect of adding nicotinamide $500 \mathrm{mg}$ per litre was examined. Table IV shows the results of these experiments with $B$. pertussis strain 18334 grown in media with either nicotinamide or nicotinic acid at concentrations of 1 or $500 \mathrm{mg}$ per litre. Organisms grown in NA500-the high nicotinic acid medium-had only about $5 \%$ of the PA and $20 \%$ of the HSF that was present in cells from X medium or from media with 1 or $500 \mathrm{mg}$ 
per litre of nicotinamide. A medium containing nicotinic acid $1 \mathrm{mg}$ per litre gave vaccine with reduced $\mathrm{PA}$ and HSF in comparison with $\mathrm{X}$ medium. The $28 \mathrm{k}$ and $30 \mathrm{k}$ gel lines were closely correlated with the presence of PA and HSF, because envelopes from organisms grown in NA500 medium resembled $\mathrm{C}$-mode envelopes in lacking these characteristic bands.

Two other B. pertussis strains, nos. 134 and GL353Z, were also grown in NA500 medium in parallel with X medium and assayed as above. Table V shows that, as with strain 18334, a high concentration of nicotinic acid suppressed PA and HSF; and the 28k and 30k gel lines were also absent (fig. 2). For comparison, this figure also includes the band pattern of a phase-IV envelope-preparation to show that the $28 \mathrm{k}$ and $30 \mathrm{k}$ bands that disappear in high-magnesium or high-nicotinic acid cultures are the bands that also disappear during phase variation. Differences in some of the high-molecular-weight bands were also noted, but these were not as consistent as the changes in the $28 \mathrm{k}$ and $30 \mathrm{k}$ bands.

As with some $\mathrm{C}$-mode vaccines, those from the high-nicotinic-acid cultures were difficult to assay satisfactorily in the mouse-protection test, and to a lesser extent in the HSF test, because of their very low potency. For this reason the confidence limits were not always given on the computer print-out.

\section{Effect of sodium sulphate and sodium succinate}

Lacey (1960) examined a large number of salts-over 100 -for their ability to produce antigenic modulation of $B$. pertussis, and $\mathrm{MgSO}_{4}$ was one of the most convenient. $\mathrm{Na}_{2} \mathrm{SO}_{4}$ when tested in "chemically equivalent amounts" was less potent than $\mathrm{MgSO}_{4}$ but also induced C-mode growth, while sodium succinate gave an intermediate antigenic state (I-mode). To explore the effects of these salts, the usual $5 \mathrm{~g}$ per litre $\mathrm{NaCl}(0.086 \mathrm{~N})$ was omitted from X medium and replaced by either $6.12 \mathrm{~g} \mathrm{Na}_{2} \mathrm{SO}_{4}$ or $11.6 \mathrm{~g}\left(\mathrm{CH}_{2} \cdot \mathrm{COONa}\right)_{2} \cdot 6 \mathrm{H}_{2} 0$ to give $0.086 \mathrm{~N}$. Cultures of $B$. pertussis strain 18334 were grown in these media in parallel with ordinary $\mathrm{X}$ medium, and vaccines and envelopes prepared as before. The results in table VI show that cells grown in the $\mathrm{Na}_{2} \mathrm{SO}_{4}$ medium contained only about $16 \%$ of the PA and $31 \%$ of the HSF as compared with vaccine from $X$ medium. The $28 \mathrm{k}$ and $30 \mathrm{k}$ gel lines in the envelopes of these cells were less prominent than those in the corresponding X-mode envelopes (fig. 4) although not as attenuated as in the C-mode (fig. 3).

The cells grown in the succinate medium appeared to possess only $41 \%$ of the PA and $29 \%$ of the HSF of the control culture although in this case, the $28 \mathrm{k}$ and $30 \mathrm{k}$ gel lines were not detectably diminished.

\section{Discussion}

Lacey $(1951,1960)$ introduced the terms X- and C-mode to describe $B$. pertussis cultures harvested from ordinary or modified BG-agar media. For convenience in this and the previous paper (Parton and Wardlaw, 1975), we have employed the same terms for cultures from conventional and modified 


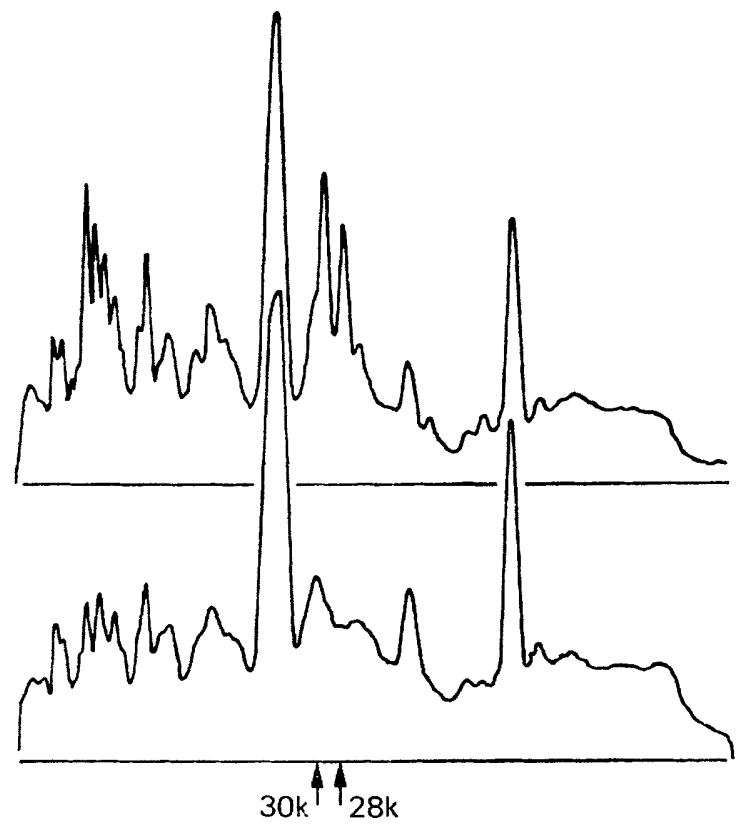

FIG. 3.-Densitometer traces of envelope proteins of B. pertussis strain 18334 grown in $\mathrm{X}$ medium (top) and C medium (bottom).

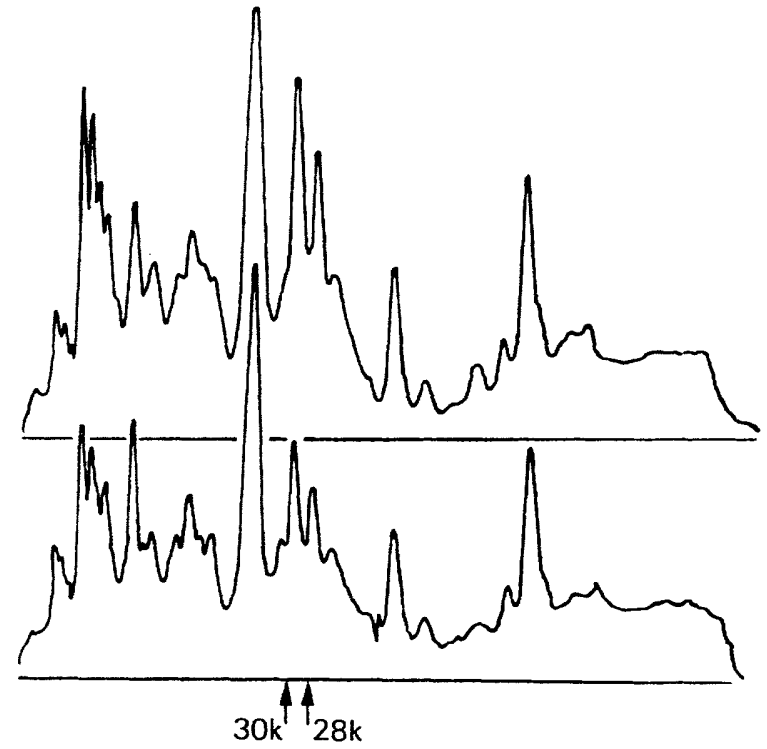

FIG. 4.-Densitometer traces of envelope proteins of $B$. pertussis strain 18334 grown in X medium (top) and $\mathrm{Na}_{2} \mathrm{SO}_{4}$ medium (bottom). 
TABLE VI

$P A$ and HSF activities, and SDS-PAGE lines, in cultures of $B$. pertussis strain 18334 from media with high levels of sodium sulphate or succinate

\begin{tabular}{|c|c|c|c|c|}
\hline \multirow{2}{*}{$\begin{array}{c}\text { Culture } \\
\text { medium } \\
\text { (and special feature) }\end{array}$} & \multicolumn{2}{|c|}{$\begin{array}{l}\text { Potency of vaccine relative to } \mathrm{X} \text {-vaccine } \\
\text { (and } 95 \% \text { confidence limits) in respect of }\end{array}$} & \multicolumn{2}{|c|}{$\begin{array}{l}\text { SDS-PAGE lines } \\
\text { in cell-envelopes }\end{array}$} \\
\hline & PA & HSF & $28 \mathrm{k}$ & $30 \mathrm{k}$ \\
\hline $\begin{array}{l}\mathrm{X} \\
\mathrm{Na}_{2} \mathrm{SO}_{4}(6 \cdot 12 \mathrm{~g} \text { per litre }) \\
\text { Succinate }(11.6 \mathrm{~g} \text { per litre })\end{array}$ & $\begin{array}{c}1 \cdot 0 \\
0 \cdot 16(0.03,0.6) \\
0.41(0.09,1 \cdot 6)\end{array}$ & $\begin{array}{c}1.0 \\
0.31(0.20,0 \cdot 47) \\
0.29(0 \cdot 19,0.44)\end{array}$ & $\begin{array}{l}+ \\
\pm \\
+\end{array}$ & $\begin{array}{l}+ \\
\pm \\
+\end{array}$ \\
\hline
\end{tabular}

$+=$ Present $\pm=$ less prominent than in vaccine grown on $\mathrm{X}$ medium.

casamino-acid liquid media. Perhaps this usage is not fully justified; nevertheless our "C-mode" organisms were only poorly agglutinable by antisera against phase-I (X-mode) cells. Also, Lacey emphasised that in his extensive survey of over 100 salts added in high concentration to BG medium, there was no evidence for a family of different C-modes. Rather, there appeared to be a single phenotypic end-result which could be reached by diverse routes.

Holt and Spasojevic (1968) used the term C-mode for B. pertussis grown on Cohen and Wheeler's casamino-acid medium containing a high concentration (45 mM) of magnesium sulphate. These cultures had less protective activity than X-mode cultures when assayed in the intracerebral mouseprotection test, although data suitable for calculating relative potencies were not reported.

The present investigation was concerned with correlating the changes in the PA and HSF activities, which resulted from growth in different media, with the presence or absence of the 28k and 30k bands in SDS-PAGE profiles. In general, a rather simple and consistent pattern of results has emerged: each of five phase-I $B$. pertussis strains cultivated in high- $\mathrm{MgSO}_{4}$ medium yielded vaccines with substantially diminished amounts of PA and HSF, and envelopes without prominent $28 \mathrm{k}$ or $30 \mathrm{k}$ polypeptide bands. Similar results were obtained with the high-nicotinic-acid medium (NA500) where, with three strains, there were also parallel losses in PA, HSF and the 28k and 30k gel lines. So far, these correlations are only qualitative, partly because of the inherently low precision of the mouse-protection test and partly because SDS-PAGE was used here only as a semi-quantitative technique. We have, however, made densitometer tracings of the gels and shown that with $\mathrm{Na}_{2} \mathrm{SO}_{4}$-grown cells there was a significant diminution of the $28 \mathrm{k}$ and $30 \mathrm{k}$ lines. This was correlated, at least semi-quantitatively, with the partial loss of PA and HSF in the corresponding vaccine. It also agrees with the finding that $\mathrm{Na}_{2} \mathrm{SO}_{4}$ is a less potent modulator than $\mathrm{MgSO}_{4}$ when tested at a chemically equivalent concentration (Lacey, 1960).

A possible discrepancy in the correlation between PA, HSF and gel lines, which requires further investigation, was provided by succinate-grown cells. 
PA and HSF were reduced (the PA not significantly) in vaccines prepared from these cells, but no appreciable diminution of the $28 \mathrm{k}$ and $30 \mathrm{k}$ gel lines was observed in the envelope-protein profiles.

In both the high- $\mathrm{MgSO}_{4}$ and high-nicotinic-acid media, the decline in PA was generally somewhat greater than that of HSF. Cells from high- $\mathrm{MgSO}_{4}$ medium had (on average in all the tests) only about $4 \%$ of the PA activity of X-mode controls, whereas the HSF was at a level of $6 \%$. With highnicotinic acid medium and strain 18334, the PA fell to $5 \%$ of the control whereas HSF only fell to $19 \%$. In the $\mathrm{Na}_{2} \mathrm{SO}_{4}$ medium, PA dropped to $16 \%$ whereas HSF fell to $31 \%$ of the control. Thus, even allowing for the low precision of the mouse-protection test, there does seem to be a definite tendency for PA to decline more sharply during antigenic modulation than does HSF. Pusztai and Joó (1967) noted the same effect with three strains grown in highnicotinic-acid medium. These authors also stated that the changes produced by high-nicotinic acid were not the same as " antigenic modulation".

In recent years there has been a sharp division of opinion about the relationship between PA and HSF. According to the "unitarian hypothesis" of Levine and Pieroni (1966), PA and HSF activities are different biological manifestations of the same pertussis cell-wall protein. This hypothesis emerged from data on the heat and trypsin sensitivity of these activities and their parallel fractionation in cell extracts. More recently, Sato, Arai and Suzuki (1974) have prepared highly purified leucocytosis-promoting factor of $B$. pertussis and shown that PA and HSF activities were also present. On the other hand, Dolby (1958), Cameron (1967), Preston and Garrity (1967), and Nagel (1970) have produced substantial evidence that PA and HSF do not necessarily occur in a fixed ratio of activities. This suggests that two distinct components exist. However, despite the large number of $\boldsymbol{B}$. pertussis strains that must have been examined during the past 25 years, there are no reports of any strain possessing PA and completely lacking HSF, or vice versa. Yet such strains would be expected to have been seen if two distinct components exist. It therefore seems likely that the unitarian hypothesis is substantially correct, but that there may be subsidiary factors that regulate the quantitative expression of PA and HSF activities in the mouse about which little is known.

The results presented here tend to support the unitarian hypothesis because of the parallelism of the changes produced in PA and HSF by growth in the different media. As an extension of the hypothesis, the present evidence suggests that the pertussis component postulated as bearing the PA and HSF activities may be represented by, or closely associated with, the $28 \mathrm{k}$ and $30 \mathrm{k}$ lines in SDS-PAGE. Because the intensity of these two lines always changed in parallel, they may-in the intact cell-constitute a protein made up of $28 \mathrm{k}$ and $30 \mathrm{k}$ polypeptides.

\section{SUMMARY}

Five Bordetella pertussis strains of phase I were grown in conventional casamino-acid medium and in media modified by adding high concentrations of $\mathrm{MgSO}_{4}$ or nicotinic acid. Cells grown in high-magnesium media (in the 
C-mode) had only about $4 \%$ of the protective antigen (PA) and $6 \%$ of the histamine-sensitising factor (HSF) of cells from the normal medium. Envelopes from C-mode organisms when examined by SDS-PAGE showed a loss of 28k and $30 \mathrm{k}$ polypetide bands. Similar parallel losses of PA, HSF and 28k and 30k bands were found with cells from the high-nicotinic-acid medium. A medium with a high concentration of nicotinamide gave cells with normal amounts of PA, $\mathrm{HSF}$ and 28k and 30k bands. Growth in high concentrations of $\mathrm{Na}_{2} \mathrm{SO}_{4}$ caused partial losses of PA, HSF and $28 \mathrm{k}$ and $30 \mathrm{k}$ bands, while a high-succinate medium gave cells with somewhat diminished PA and HSF but without appreciable attenuation of the $28 \mathrm{k}$ and $30 \mathrm{k}$ bands.

Because of the close correlation between the presence or absence of PA, HSF and $28 \mathrm{k}$ and $30 \mathrm{k}$ envelope polypeptides, it is suggested that the latter may represent or be closely associated with the components responsible for PA and HSF activities.

This project was supported by a grant from the Medical Research Council.

\section{REFERENCES}

AMEs, G. F. 1974. Resolution of bacterial proteins by polyacrylamide gel electrophoresis on slabs. Membrane soluble and periplasmic fractions. J. biol. Chem., 249, 634.

APRILE, M. A. 1972. A re-examination of phase IV Bordetella pertussis. Can.J. Microbiol., 18, 1793.

British Pharmacopoeia 1973. London.

Cameron, J. 1967. Variation in Bordetella pertussis. J. Path. Bact., 94, 367.

Dolby, J. M. 1958. The separation of the histamine-sensitizing factor from the protective antigens of Bordetella pertussis. Immunology, 1, 328.

Eldering, G., Eveland, W. C. AND KENDRICK, P. L. 1962. Fluorescent antibody staining and agglutination reactions in Bordetella pertussis cultures. J. Bact., 83, 745.

Herbert, D., Phipps, P. J. ANd Strange, R. E. 1971. Chemical analysis of microbial cells. In Methods in microbiology, vol. 5B, edited by J. R. Norris and D. W. Ribbons, London and New York, p. 249.

Holt, L. B. AND Spasojevic, V. 1968. The role of surface antigens in the protective potency of Bordetella pertussis suspensions as measured by the intracerebral challenge technique in mice. J. med. Microbiol., $1,119$.

HoRNIBROOK, J. W. 1939. Cultivation of phase I Haemophilus pertussis in a semisynthetic liquid medium. Publ. Hlth Rep., Wash., 54, 1847.

Kasuga, T., Nakase, Y., Ukishima, K. and Takatsu, K. 1954. Studies on Haemophilus pertussis. IV. Preventive potency of each phase organisms of Haemophilus pertussis in mice. Kitasato Archs exp. Med., 27, 49.

KIND, L. S. 1953. The altered reactivity of mice after immunization with Haemophilus pertussis vaccine. J. Immun., 70, 411.

LACEY, B. W. 1951. Antigenic modulation of Haemophilus pertussis. J. gen. Microbiol., 5 , xxi.

LACEY, B. W. 1960. Antigenic modulation of Bordetella pertussis. J. Hyg., Camb., 58, 57.

LAEMMLI, U. K. 1970. Cleavage of structural proteins during the assembly of the head of bacteriophage T4. Nature, Lond., 227, 680.

Leslie, P. H. and GardneR, A. D. 1931. The phases of Haemophilus pertussis. J. Hyg., Camb., 31, 423.

Levine, L. AND PIERoNI, R. E. 1966. A unitarian hypothesis of altered reactivity to stress mediated by Bordetella pertussis. Experientia, 22, 797. 
NAGEL, J. 1970. Investigations into the preparation of a non-toxic whole-cell pertussis vaccine. In: International symposium on pertussis, Bilthoven, 1969; Symp. Series Immunobiol. Standard., vol. 13, Basel, München and New York, p. 234.

Parton, R. and Wardlaw, A. C. 1974. The cell envelope proteins of Bordetella pertussis in relation to phase variation and antigenic modulation. Proc. Soc. gen. Microbiol., $1,78$.

Parton, R. and Wardlaw, A. C. 1975 . Cell envelope proteins of Bordetella pertussis. J. med. Microbiol., 8, 47.

Preston, N. W. AND GARRITY, P. 1967. Histamine-sensitising factor of Bordetella pertussis differentiated from immunogens by neutralisation and passive protection tests. $J$. Path. Bact., 93, 483.

PuszTaI, S. AND Joo, I. 1967. Influence of nicotinic acid on the antigenic structure of Bordetella pertussis. Annls Immunol. hung., 10, 63.

Sato, Y, ARAI, H. AND SUzUKI, K. 1974. Leukocytosis-promoting factor of Bordetella pertussis. III. Its identity with protective antigen. Infect. Immun., 9, 801 .

WARDLAW, A. C. AND JAKUS, C. M. 1966. The inactivation of pertussis protective antigen, histamine-sensitizing factor and lipopolysaccharide by sodium metaperiodate. Can. J. Microbiol., 12, 1105.

WeBer, K. AND OsBORN, M. 1969. The reliability of molecular weight determinations by dodecyl sulphate-polyacrylamide gel electrophoresis. J. biol. Chem., 244, 4406. 